\title{
BEYOND THE NORTHERN INVASION: THE MEDITERRANEAN IN THE SEVENTEENTH CENTURY
}

Fernand Braudel's magisterial work, The Mediterranean and the Mediterranean World in the Age of Philip II, is a study of the sixteenth century, but he does, nevertheless, look forward to the following century, during which he posits a 'Northern Invasion'. The northern invasion argument asserts that the Dutch, the English and the French swarmed into the Mediterranean with their superior sailing ships early in the seventeenth century, and seized control of the sea's commercial, financial and maritime life. ${ }^{1}$ This picture has been endorsed by many others, and is easily the dominant model for the Mediterranean world in the seventeenth century. ${ }^{2}$

But the northern invasion thesis is not only an argument about numbers and relative strength. It also asserts that economic competition between nation states replaced the old religious rivalry. The assertive language used implies that the arrival of the northern Europeans on the Mediterranean scene heralded a decisive break with the old conflict between Islam and Christianity and

${ }^{1}$ It is at the end of his first volume that Braudel describes the northern invasion of the Mediterranean: Fernand Braudel, The Mediterranean and the Mediterranean World in the Age of Philip II, trans. Siân Reynolds, 2 vols. (New York, 1972), i, 615-42.

2 'If the eastern Mediterranean was in the process of sliding slowly and unconsciously into dependence on the Westerners ... parallel to this hold of the West over the East, there was another conquest on the western side, the conquest of the South by the North': Michel Fontenay, 'The Mediterranean, 1500-1800: Social and Economic Perspectives', in Victor Mallia-Milanes (ed.), Hospitaller Malta, 1530-1798: Studies on Early Modern Malta and the Order of St. Fohn of Ferusalem (Msida, 1993), 52. Bruce Masters slides quickly from the age of Italian pre-eminence to the northern conquest when he writes of 'the triumph of the northern Europeans over their southern European rivals in both the Levant and the Indian Ocean': Bruce Masters, The Origins of Western Economic Dominance in the Middle East: Mercantilism and the Islamic Economy in Aleppo, 1600-1750 (New York, 1988), 75. In his seminal survey of the development of the Greek merchant marine, George Leon dates the northern invasion to the last decades of the sixteenth century, when 'French, English and Dutch merchants entered the Empire in sufficiently large numbers to eliminate Italian monopoly and ultimately ruin Italian trade with the Near East': George Leon, 'The Greek Merchant Marine, 1453-1850', in Stelios Papadopoulos (ed.), The Greek Merchant Marine (Athens, 1972), 16.

(C) The Past and Present Society, Oxford, 2002 
the beginning of a new, national world. Maurice Aymard, for example, downplays the Christian triumph at the battle of Lepanto (1571) in the light of subsequent events: "the victory of Lepanto is a deceptive one because in the decades that follow the Atlantic powers invade the Mediterranean and take it over' ${ }^{3}$ It is an understandable focus. The spectacular clashes of previous centuries (of which Lepanto was only the most recent) between Muslim and Christian powers - 'official war' as Braudel puts it - have no place in the Mediterranean's seventeenth-century history. ${ }^{4}$ Also, the period ushered in an extended struggle between the Dutch and the English (and, to a lesser extent, the French) for commercial pre-eminence in the Mediterranean, and this competition had little or no religious character. ${ }^{5}$

Yet the emphasis on economic competition between the rising states of north-western Europe, however justified on one level, obscures as much as it illuminates about the nature of the seventeenth century in the Mediterranean. Three distinguishing features deserve special attention. The first is that the idea of a quick and decisive northern European takeover of Mediterranean commerce can be defended only if one emphasizes the western Mediterranean at the expense of points further east, and longdistance trade at the expense of the lucrative caravane (as the carrying trade was known). The caravane was fiercely competitive throughout most of the seventeenth century, particularly in the eastern Mediterranean.

Second, in the messy reality of the market place, it is difficult to identify anything as clear-cut as 'Muslim' or 'French' or 'Christian' trade. Commercial competition in the seventeenth century cannot be adequately grasped by reference to either

${ }^{3}$ M. Aymard, 'La Méditerranée vue d'Istanbul', in Gilles Veinstein (ed.), Soliman le Magnifique et son temps (Paris, 1992), 71.

${ }^{4}$ The absence of major wars has also contributed to the bypassing of the Mediterranean in historiographical terms. Braudel made the following observation: 'Roger Bigelow Merriman's The Rise of the Spanish Empire, an excellent traditional history, concludes with the end of Philip II's reign in 1598. It contains no mention of any event in Mediterranean history after 1580. This silence, typical of almost all histories of Spain, is significant. For Merriman as for other narrative historians, the Mediterranean which was the scene of no major wars or diplomatic initiatives after Margliani's mission to Turkey, is suddenly plunged into darkness as other locations steal the limelight': Braudel, Mediterranean and the Mediterranean World in the Age of Philip II, ii, 1186.

${ }^{5}$ Richard Rapp, 'The Unmaking of the Mediterranean Trade Hegemony: International Trade Rivalry and the Commercial Revolution', fl Econ. Hist., xxxv (1975). 
national or religious criteria. This is partly because no one was in charge in the seventeenth century. There was no state strong enough to impose order and predictability over the marketplace. The Italian city states had lost their position of dominance - the strength of the Venetian merchant marine was cut in half between 1550 and 1590 - but France, due to internal turmoil, was not yet in a position to replace the Italians. ${ }^{6}$ The Dutch and the English were maritime powers of the first order, certainly, but their presence in the Mediterranean was intermittent. ${ }^{7}$ Throughout the century, the Ottomans had to struggle just to maintain a minimal amount of order in certain key sea lanes, like the route between Cairo and Istanbul. Thus state sovereignty over the market place was fragmented and largely unasserted, and piracy, both Christian and Muslim, soared to new heights. Given this insecurity, the search for protection was of the utmost importance in the daily practice of commercial life. The arrangements that developed out of this search cut across both religious and national lines. Similarly, the new northern powers found that it was no easy matter to press the commercial endeavours of their own nationals into the service of the state. In the literature on the seventeenth century 'the French' and 'the English' are referred to as if they were coherent and united communities. In fact the state had to struggle mightily to impose a national trade policy on a disparate collection of individuals. This will be seen in the French case, which will be discussed at length below. Economic competition along nation-state lines (national trade, in other words) was much more of an eighteenth-century phenomenon. The complexity of trade in the seventeenth century was not, however, just a result of weak states and fractious communities. The English, the Dutch and the French were all desirous of

${ }^{6}$ Dominique Sella, 'Crisis and Transformation in Venetian Trade', in Brian Pullan (ed.), Crisis and Change in the Venetian Economy (London, 1968), 92. In his monumental study of the trade of Marseilles Paul Masson characterizes the seventeenth century as one crisis after another and one in which the French were continually threatened with the ruin of their commerce: Paul Masson, Histoire du commerce français dans le Levant au XVII ${ }^{e}$ siècle (Paris, 1896), Introduction. French commerce in the ports of the eastern Mediterranean fell from 7 million livres in 1648 to 2.5 to 3 million livres in 1660. It did not begin to recover until 1685. Robert Mantran, Istanbul dans la seconde moitié du XVII ${ }^{e}$ siècle: essai d'histoire institutionnelle, économique et sociale (Paris, 1962), 556.

${ }^{7}$ Prior to 1650 , Dutch trade with the eastern Mediterranean was minimal. Late in the 1630s the Venetian Bailo observed that 'the ships which sail to Constantinople from this nation are rare and they have only two merchant houses here': Mantran, Istanbul dans la seconde moitié du XVII e siècle, 573. 
expanding their trading relations with the Ottoman Empire. Nevertheless, this ambition was not enough to wipe out a long tradition of religious hostility between Christianity and Islam. The desire to trade combined with the continuing importance of religion to form a profound moment of hesitation on the part of all parties. This hesitation was one of the seventeenth century's most characteristic features. Although commerce itself was flourishing, the foundation of the trading regime in the Mediterranean was uncertain. Was the Mediterranean a collection of sovereign states bound by treaty obligations to one another? Or was it a cultural and political frontier, where two hostile religions faced each other in perpetual enmity? Both points of view were asserted.

Third and finally, by its silence on the matter, the 'Northern Invasion' paradigm implies that religious confrontation was no longer an important part of Mediterranean history. Another body of work does directly confront the question of religion. This is the literature on the corso, as the running war between Muslim and Christian corsairs was known. ${ }^{8}$ Although the two historiographies are quite separate, the arguments of scholars of the corso fit neatly into the larger frame of the northern invasion. They argue for a decline in the crusading spirit and the normalization of trade. The corso waxed and waned depending upon conditions. There was a tremendous upsurge of such violence in the seventeenth century, after which time the corso went into a steep and, it turned out, irrevocable decline. Although historians do mention specific technical problems that contributed to its weakening, such as the advent of the Atlantic sailing ship, the more general - and most favoured - explanation is cultural in its thrust, and is an argument about tolerance: that the growth of a more tolerant spirit rendered the old religious divides, and those who lived by them, both irrelevant and anachronistic. Three pieces of research on the Knights of St John, who directed the Christian corso from their rocky perch on the island of Malta, come to the same conclusion. Earle states that the troubles the Maltese corsairs faced 'arose partly from the undoubted abuses which the corsairs themselves had introduced

\footnotetext{
${ }^{8}$ Peter Earle gives a good description of the nature of the corso war when he writes that for centuries 'the normal occupation of thousands of men in the Mediterranean was to set sail from their home ports in order to attack the shipping or the coastal regions of the area. Their victims were slaughtered or sold into slavery, their goods plundered and sold as prizes. The definition of the corsairs' enemies was that they worshipped a different God': Peter Earle, Corsairs of Malta and Barbary (London, 1970), 6.
} 
into their business, but also from changing circumstances in the Mediterranean, as commerce between Christian and Moslem increased and as religious intolerance became less marked outside Malta'. ${ }^{9}$ Mallia-Milanes observes that, as the seventeenth century wore on, the figure of the warrior-crusader no longer seemed relevant or convincing. ${ }^{10}$ And a student of Maltese institutions notes that, at the end of the seventeenth century, the Maltese set up a regular commercial court to handle the 'normal' trade that was slowly replacing the profits of the corso.

The international developments whereby European states began to come to terms with the Ottoman Empire and individual North African beys, was to signal the decline of corsairing. The corso flourished only as long as Muslims were feared, but once normal trading relations were established it became a nuisance to trade . . . the Order's crusading ideal was becoming more anachronistic. ${ }^{11}$

This view of the seventeenth century has clear undertones of modernization theory: gradually violence gave way to a more 'normal' set of arrangements characterized by religious tolerance and open and peaceful trade between states, both Christian and Muslim. In addition to its Whiggish assumptions, the argument is of little help in explaining important features of the seventeenth century. The progressive exclusion of Muslims from the commercial and maritime life of the sea, for example, suggests the continuing significance of religion in the pursuit of profit. It was the deployment of religion that changed towards the end of the seventeenth century. Prior to that solidarity or antagonism on the basis of religious identity had been an optional strategy for individual merchants and pirates. As the French and the English consolidated their control over the commerce of the Mediterranean, this option was gradually dismantled. Instead, religion became a tool in support of commerce directed by, and for the benefit of, the state.

\section{THE NORTHERN INVASION}

The 'Northern Invasion' remains one of the few self-confident and unproblematic triumphs still standing in the historiography

${ }^{9}$ Ibid., 109.

${ }^{10}$ Victor Mallia-Milanes, Venice and Hospitaller Malta (Marsa, 1992), p. xix.

${ }^{11}$ Sebastian Vella, 'The Consolato del Mare of Malta: A Study of an Institution (1697-1725)' (Univ. of Malta BA thesis, 1998), 12. 
of what used to be known as the expansion of the West. Braudel used a vivid metaphor to convey a sense of total northern victory: 'So the Dutch swarmed into the Mediterranean like so many heavy insects crashing against the window panes - for their entry was neither gentle nor discreet'. ${ }^{12}$ Michel Fontenay's recent (1993) survey of the Mediterranean between 1500 and 1800 uses equally dramatic language: 'this sudden invasion by the Northerners'; and 'this general overthrow of the Mediterranean'. ${ }^{13}$ This argument, however, is misleading. Whilst the long-distance trade between the Mediterranean and Europe, which has received a good deal of attention, was indeed wrested from Italian hands by the English, the Dutch and, to a lesser extent, the French, this does not mean that all Mediterranean commerce fell under northern control. ${ }^{14}$ The lucrative and extensive carrying trade of the Mediterranean - the so-called caravane - remained highly competitive and contested throughout the seventeenth century, only giving way to English and French domination towards its end. ${ }^{15}$ This was particularly true

${ }^{12}$ Braudel, Mediterranean and the Mediterranean World in the Age of Philip II, i, 634.

${ }^{13}$ Fontenay, 'Mediterranean, 1500-1800', 81-2. For a long time now a minority of scholars have argued against this point of view but have not been able to puncture the thesis of the Northern Invasion. Robert Paris, historian of Marseilles and its commerce, describes the seventeenth century in the following way: 'Between the decline of the Portuguese and Spanish navies and the rise of the maritime powers of Holland, France and England, there was an interregnum which profited those who lived off plunder. In the Antilles it is the golden age of the buccaneers and the filibusters while in the Mediterranean it is that of the Barbary chiefs': Robert Paris, Histoire du commerce de Marseille, v, De 1660 à 1789: Le Levant (Paris, 1957), 182. While I do not agree that the Caribbean and the Mediterranean are directly comparable, his argument for an interregnum is valuable.

${ }^{14}$ And trades that had been lost could be regained. For example, in the 1620 s the Venetians regained control of several trades that had been lost to the Dutch, such as the export of cotton goods from Egypt and Cyprus to Germany: see Jonathan Israel, Dutch Primacy in World Trade, 1585-1740 (Oxford, 1989), 152.

${ }^{15}$ Commercial histories of the Mediterranean often fail to distinguish adequately between the caravane trade and international trade. The enormous divide between this sector of the economy and the world of international trade can perhaps be best appreciated by comparing a description of the caravane trade with that of the Dutch convoy which sailed to the Levant twice a year: 'the small ships of Marseilles . . . had long since found an economic "niche" by transporting small quantities of goods on behalf of merchants operating from Mediterranean ports. The carrying trade or "caravane" operating between Ottoman port towns constituted but one example of such services rendered on a small scale to individual customers': Suraiya Faroqhi, 'Trade: Regional, Interregional and International', in Halil Inalcik with Donald Quataert (eds.), An Economic and Social History of the Ottoman Empire, 1300-1914 (Cambridge, 1994), 522. The pepper trade operated at a different level altogether: "The Dutch Smyrna convoy of six "great ships" and two men-of-war which docked 
in the eastern Mediterranean, which tends to be the lesser-known half of the inland sea.

As Braudel himself acknowledged, the southern and eastern part of the Mediterranean is 'the great unknown of all studies of the sixteenth century'. ${ }^{16}$ This is just as true for later periods. When one views the seventeenth century from the vantage point of the eastern Mediterranean, the invasion of the northerners is not the most important event. If in the western Mediterranean historians have been distracted by the fireworks between the English and the Dutch on the one hand, and the Spanish on the other, further east the steady disintegration of Italian, and particularly Venetian, sea power worked slowly to reorganize commercial, and even social life, in ways that were perhaps less dramatic, but just as significant in the long run as the defeat of the Spanish Armada in 1588. Venice's decline vis-à-vis the Atlantic powers is well known and well documented and need not be dwelt upon here. What is interesting in the present context is that the Italian retreat from the eastern Mediterranean ushered in a period when no one power, whether European or local, dominated the carrying trade in the eastern Mediterranean. ${ }^{17}$

The inability of any one power to dominate the carrying trade in the first half of the seventeenth century, plus high levels of piracy, have encouraged the use of words like 'anarchic' or 'depressed' to describe contemporary conditions. ${ }^{18}$ But anarchy can be a boon for smaller powers. It was the seventeenth century that witnessed the ascendancy of Greek maritime power, an important development that is absent from general accounts of the Mediterranean in that period. ${ }^{19}$ Greek sea-captains and sailors

(n. 15 cont.)

at Livorno in September 1670 en route to the Levant carried 600,000 lb. of pepper in 1,700 bales, an amount equivalent to over 10 per cent of Europe's total annual pepper consumption': Israel, Dutch Primacy in World Trade, 227.

${ }_{16}$ Braudel, Mediterranean and the Mediterranean World in the Age of Philip II, ii, 1245 .

17 'The last quarter of the sixteenth and first half of the seventeenth centuries was indeed a most difficult period for the policing of the seas: Turkey had now withdrawn to the eastern Mediterranean; the navies of the Italian states had declined; French naval power had been exhausted during the Wars of Religion and the Spanish navy had been exhausted by the Dutch and Elizabethan wars. International anarchy and the exhaustion of the Mediterranean naval powers proved a fertile soil for piracy': Leon, 'Greek Merchant Marine', 18.

${ }^{18}$ See B. J. Slot, Archipelagus turbatus: les Cyclades entre colonisation latine et occupation ottomane, c.1500-1718 (Istanbul, 1982), 21.

${ }^{19}$ Michel Fontenay, historian of the Maltese corso in the seventeenth century, is one of the very few to acknowledge the importance of Greek shipping in the seven- 
moved swiftly into the vacuum left by Venice and assumed a leading role in the caravane trade in the eastern and central Mediterranean. Evidence can be found from all parts of the Aegean. B. J. Slot, for instance, has documented the rise, in the early seventeenth century, of a Cycladic shipowning class that traded in silk, wheat and cotton. The island of Sifnos alone had thirty-eight boats, a remarkable number, when considering that the population did not exceed three thousand. ${ }^{20}$ Also, on the island of Crete, which was still under Venetian rule throughout most of the seventeenth century, local shipping took over in the wake of the dramatic decline of Venice's merchant marine. As early as the middle of the sixteenth century Cretans were sailing to southern Italy; a certain George Noufris even reached Flanders in 1539. A Venetian official in Crete in 1589 wrote:

The cities, and especially Candia [Herakleion] and Chania, produce many good sailors. It is said, as a proverb, that when a villager is born in Crete, a galley slave is born, and when a child is born in the city a sailor is born. The Cretans sail with their boats in times of peace to Smyrna, Syria, Turkey and the Archipelago and to other places in Turkey in every sort of boat and skiff; they are skilful and daring men. ${ }^{21}$

Venice must have been a common destination for this new Greek ship-owning class, because in the mid-sixteenth century the Greek community in Venice decided to levy a tax on every Greek boat that anchored in the city's port. The tax was intended to help pay for the construction of the Church of St George of the Greeks, which was the centre of the community. ${ }^{22}$

On the island of Patmos ships belonging to the Monastery of St John enjoyed a period of tremendous prosperity in the late sixteenth and seventeenth centuries. An Isolario from 1590 said

\footnotetext{
(n. 19 cont.)

teenth century. He notes: 'the Greeks were often the first victims of the corsairs, in part because they were the principal maritime carriers in the Empire'. Michel Fontenay, 'Corsaires de la foi ou rentiers du sol? Les chevaliers de Malte dans le "corso" méditerranéen au XVII ${ }^{\mathrm{e}}$ siècle', Revue d'histoire moderne et contemporaine, xxxv (1988), 368.

${ }^{20}$ Slot, Archipelagus turbatus, 160-1.

${ }^{21}$ Stergios Spanakes, 'Relazione del nobil huomo Zuanne Mocenigo ritornato Provveditore Generale del Regno di Candia presentata nell'eccellentissimo Consillio 17 Aprile 1589', Mnemeia tes kretikes istorias [Monuments of Cretan History] (Herakleion, 1940), i, 23.

${ }^{22}$ Kristas Panayiotopoulos, 'Ellenes nautikoi kai ploioktetes apo ta palaiotera oikonomika vivlia tes Ellenikes Adelfotetes Venetias, 1536-1576' [Greek Sailors and Shipowners According to the Oldest Account Books of the Greek Society of Venice], Thesaurismata, xi (1974), 288.
} 
the island was 'well-populated by many people who are all seamen ... they have innumerable ships that navigate on the convent's account'. ${ }^{23}$ From the memoirs of a merchant of Patmos, one Iakovos Miliote, written around the year 1588, it is clear that the Patmiots regularly sailed not only throughout the eastern Mediterranean, but to southern Italian ports as well. ${ }^{24}$ Around 1580 the islanders were apparently living so well that the Archbishop of Alexandria, on the island for a visit to the Monastery of St John the Divine, felt the need to admonish the Patmiots to submit to the head of the monastery, to fast and to live as good Christians should. It was in the seventeenth century that the large houses of the island's capital city were built. ${ }^{25}$ Greek commercial relations with the island of Malta, too, were so important in the seventeenth century that the Grand Master chose to retain a Greek consul to facilitate the business - legal or otherwise - of Greek Orthodox merchants, sailors and shippers who had occasion to come to the island. ${ }^{26}$

If the Greek islanders, moving swiftly to capitalize on Venetian weakness, pushed out into the hazardous waters of the central Mediterranean, a more solid and established merchant class continued to thrive in Istanbul. The Ottoman capital, as many historians have noted, was a vast centre of consumption. Istanbul merchants and some provincial commercial elites earned a good and steady living by provisioning the population of the capital, drawing on the enormous hinterland of the Empire. Their presence in the eastern Mediterranean was strengthened by the fact that they had access to the ports of the Red and the Black Seas, areas that were off limits to foreigners. ${ }^{27}$ Private ships, captained by both Muslims and Christians, departed daily for destinations in the Aegean, and this dense network of routes meant that the

${ }^{23}$ Antonio di Milo, Isolario, quoted in St. A. Papadopoulos, Patmos (Athens, 1967), 60.

${ }^{24}$ Anna Marava-Xatzinikolaou, Patmos (Athens, 1957), 39.

${ }^{25}$ Ibid.

${ }^{26}$ Mallia-Milanes, Venice and Hospitaller Malta, 226. The first Greek consulate on the island was established in 1623 . The consul was entitled to an ad valorem fee of 2 per cent every time he assisted a Greek merchant in carrying out a business transaction on the island.

${ }^{27}$ Travellers were often struck by the fact that the Ottomans had within their borders all the materials necessary for the construction of ships: Mantran, Istanbul dans la seconde moitié du XVII e siècle, 445. 
Aegean was still, even in the seventeenth century, an Ottoman sea. ${ }^{28}$

The most vital north-south link was the route connecting Alexandria to northern Ottoman ports, particularly Istanbul. Egypt was Istanbul's breadbasket, and the desire to protect this route from corsairs was a primary reason for the Ottoman attempt, eventually successful, to wrest Crete away from the Venetians in the middle of the seventeenth century. Egypt's trade with Istanbul was enormous; as late as the last quarter of the eighteenth century trade with the capital city alone was greater than all of Egypt's trade with Europe. ${ }^{29}$ Wood from southern Anatolia was regularly exported to Alexandria. The trade between Egypt and the rest of the Ottoman Empire was remarkably stable, free from the violent fluctuations that characterized exports to Europe. $^{30}$

Ottoman merchants, including Muslims, were very prominent in this continuous traffic, both as traders and as shippers. Most of Alexandria's trade with more northern Ottoman ports was in the hands of Muslims from Kos and Crete, and most of the wood exported from Anatolia to Egypt was carried in Ottoman ships. ${ }^{31}$ Of course nothing rivalled the importance of the grain shipments from Alexandria to Istanbul. Whether Ottoman ships were hired to carry this precious cargo is an unresolved issue, but significant indigenous participation can certainly not be ruled out. ${ }^{32}$

${ }^{28}$ Mantran calls it 'la mer ottomane par excellence': ibid., 490.

${ }^{29}$ André Raymond, Artisans et commerçants au Caire au XVIII ${ }^{e}$ siècle, 2 vols. (Damascus, 1973), i, 188.

${ }^{30}$ The farming of a French consulate, by contrast, was an extremely speculative business precisely because the volume of trade fluctuated so violently: Neils Steensgaard, 'Consuls and Nations in the Levant from 1570 to 1650', Scandinavian Econ. Hist. Rev., xv (1967), 31.

${ }^{31}$ Raymond, Artisans et commerçants au Caire, i, 201, 168.

${ }^{32}$ Raymond does not discuss the role of Muslim shippers specifically in the context of grain shipments to Istanbul. Mantran does, however, observing that, in sharp contrast with other routes, the Ottomans hired foreign ships - Venetian, English and French - for the caravane between Alexandria and Istanbul; but he fails to say why he dismisses a French report of 1669 (the year of the final conquest of Crete) which said that the Ottomans very rarely hired Christian ships to transport goods from one port to another: Mantran, Istanbul dans la seconde moitié du XVII ${ }^{e}$ siècle, 491. A firman dated 1719 was published a little over a decade ago by Michael Winter, the historian of Ottoman Egypt. The firman testifies to the existence of a significant group of Muslim shippers trading between Egypt and the ports of Izmir, Thessaloniki and Istanbul. It also shows that the Ottoman government was concerned to protect Ottoman shipping, although this does not mean it was effective in doing so. The firman states: 'As long as there are [Muslim] merchants' galleons [present] in the 
Turning to the carrying trade in the western Mediterranean, trade between North African and Italian ports has been overlooked in favour of the development of Livorno as a way station between east and west. The English were, it is true, a formidable presence at Livorno, but trade between North Africa and southern Europe remained competitive throughout most of the century. Before 1680 Tuscans and Corsicans handled most of the traffic between Tunis and Livorno; thereafter, that role was ceded to ships from Provence and Languedoc. ${ }^{33}$

\section{II}

\section{COMMERCIAL ALLIANCES}

The northern Europeans, then, were just one group among many in the complex of commercial activity in the seventeenth century. They were not in a position to impose their will on the marketplace; nor was anyone else. The result was a fairly egalitarian but also anarchic commercial world where conventional distinctions such as European/local and Christian/Muslim are less than useful. An early seventeenth-century document from the English Admiralty Court spoke of a 'time of libertie and deceipte, when soe manie banners and collours are promiscuouslie used at sea to disguise themselves and intrapp others [that it is not possible] to knowe which ships are pyrattical or not'. ${ }^{34}$

In a chaotic century the pursuit of profit meant, first and foremost, a search for adequate protection. This resulted in some rather striking relationships of convenience. Muslim naval powers protected Christian shipping against Muslim piracy, and Muslim merchants invoked Christian protection against Maltese attacks on their shipping. Corsairing, too, was less and less structured along the lines of the 'eternal war' between Christianity and Islam; Christian pirates, in particular, were just as willing to attack other Christians as they were to attack Muslims. To the

(n. 32 cont.)

harbour of Alexandria, nothing is to be loaded on alien [müste'min] ships to be carried to the harbours of Istanbul, Izmir and Salonica'. Michael Winter, 'A Statute for the Mercantile Fleet in Eighteenth-Century Egypt', Mediterranean Hist. Rev., iii (1988), 120.

${ }^{33}$ B. Sadok, La Régence de Tunis au XVII e siècle: ses relations commerciales avec les ports de l'Europe méditerranéenne, Marseille et Livourne (Ceroma, 1987), 100.

${ }^{34}$ Documents Relating to Law and Custom of the Sea, ed. R. G. Marsden, 2 vols. (Navy Records Soc. Pubns, xlix-1, London, 1915-16), i, 379. 
average Englishman in the early seventeenth century the Barbary pirates were not North African Muslims at all, but rather those adventurers, mostly English, who had established themselves along the North African coast, originally with the aim of attacking Spanish shipping. ${ }^{35}$ Both the North Africans and the French and there may have been others - were willing to sell safeconduct passes to a wide variety of petitioners. French consuls in the Levant provided these for Muslim merchants and shipowners. The passes would then be produced by Muslim victims (or potential victims) when meeting up on the high seas with the Maltese, or taken to Malta itself when a capture was being contested. $^{36}$ The North Africans, too, provided safe-conduct passes, although of limited number, for all nations, including their purported enemies the Maltese. ${ }^{37}$ Considering that these passes 'were bought, sold or forged, thus complicating the situation still further', it is easy to agree with Earle that the Mediterranean was a very 'awkward' sea to sail in. ${ }^{38}$

At the same time, it is necessary to take account of the difficult fact that certain apparently impermeable boundaries were actually crossed with some regularity and little fuss. Until the last quarter of the seventeenth century the itinerary 'Tunisia, Sicily, Malta' was routinely sailed by a throng of small vessels belonging to the merchants of Tunis, Sousse, Sfax and Jerba. ${ }^{39}$ The French merchant d'Arvieux wrote from Tunisia: ' $[t]$ he ports of this kingdom are free to all the world ... The Maltese even, although the irreconcilable enemies of the Tunisians and of all the people of Barbary ... come here laden with their own flags displayed'. ${ }^{40}$ But, although Tunisians regularly sailed into Sicilian ports, Muslim travellers were not always secure even on well-armed English and Dutch ships. ${ }^{41}$ In 1651 an English ship, the Goodwill, was carrying thirty-two Turks from Tunis to Smyrna. On the way the ship encountered some Maltese galleys, and the captain one Stephen Mitchell - gave up his passengers for a large sum

\footnotetext{
${ }^{35}$ G. Fisher, Barbary Legend: War, Trade and Piracy in North Africa, 1415-1830 (Oxford, 1957), 138.

${ }^{36}$ Roberto Cavaliero, 'The Decline of the Maltese Corso in the XVIIIth Century', Melita Historica, viii (1959), 226.

${ }^{37}$ Earle, Corsairs of Malta and Barbary, 32.

${ }^{38}$ Ibid., 45.

${ }^{39}$ Sadok, La Régence de Tunis, 98.

${ }^{40}$ Earle, Corsairs of Malta and Barbary, 32.

${ }^{41}$ English and Dutch ships enjoyed the reputation of being well armed and very secure: ibid., 53.
} 
of money. The consequences of this action grew to the point where England and Tunis went to war. What is significant is that in the treaty which concluded this war there was a specific clause commanding English captains to defend their Tunisian passengers in the future 'as far as is in their power' ${ }^{42}$ Although negotiated at the highest diplomatic levels, this was simply another manifestation of the unending search for security in the seventeenth century.

The story of Stephen Mitchell and his unfortunate Muslim passengers introduces another entirely characteristic aspect of the period. Since Tunis and England, having signed a treaty, were at peace in 1651, Stephen Mitchell should not have abused his passengers in this way. ${ }^{43}$ The fact that he did so nevertheless shows the real difficulties that England and the other northern powers faced in imposing state policy on their own nationals operating in the Mediterranean.

It is worth looking more closely at the difficulties faced by France in this regard. There are two reasons for this focus on the French case. First, amongst the northerners it was the French who were the most active by far in the caravane trade, which is the sector of the economy most relevant to this article. ${ }^{44}$ Second, the French presence in the Mediterranean was far more complicated than that of either the Dutch or the English. ${ }^{45}$ This was due in part to the very nature of the caravane trade: continuous journeys around the Mediterranean with stops at every port in search of small amounts of cargo meant frequent interventions into the market, and all the consequent uncertainties. The ambition of French missionaries and, at times, the French crown to establish some sort of protectorate over the Catholics in the eastern Mediterranean added another layer of complexity.

42 Ibid., 39.

${ }^{43}$ Of course his action could also be decried on more customary grounds since it violated the contract that he had made with his passengers. But here I am concerned with the relationship between an English captain and English state policy.

${ }^{44}$ The very different nature of the French and the English presence in the Mediterranean is indicated by the number of ships belonging to each nation around the year 1600. Ships flying the English flag were less than forty while around one thousand flew the French. Masson, Histoire du commerce français dans le Levant, 31; A. C. Wood, A History of the Levant Company (London, 1935), 23.

${ }^{45}$ Although the Dutch and the English were stronger economic powers, Robert Mantran devotes just eight pages to them combined, while his discussion of the French runs for eighteen pages: Mantran, Istanbul dans la seconde moitié du XVII siècle, 570-8, 552-69. 
Thus, to speak of 'the French', in the seventeenth-century Mediterranean, is really to speak of numerous actors - the crown, French missionaries, consuls around the Mediterranean, the Chamber of Commerce of Marseilles, and the merchant communities established in the ports of the Ottoman Empire - all of whom were, as often as not, pulling in different directions.

In the first half of the seventeenth century the French crown was animated by a great missionary zeal. Although Spain and France were enemies in Europe, in the Ottoman East it was France who represented the expansionist Catholicism of the Counter-Reformation. ${ }^{46}$ Philippe de Harlay, comte de Césy, the king's ambassador in Istanbul throughout the 1620s, was also the formal representative of the 'Roman Propaganda', the commission founded in 1622 to establish a sort of protectorate over the Catholics of the Levant. Césy and the Pope worked to get French missionaries, sympathetic to the Counter-Reformation, appointed to vacant bishoprics in the Aegean. Césy also fought for control over the Sacred Places in Jerusalem, the Latin churches in places like Constantinople and Aleppo, and, especially, the political and religious orientation of the Greek Patriarchate. In all of this he was met with fierce Venetian resistance. It is important to note that Venice, a representative of the 'old' Mediterranean, would never have tolerated that the Bailo in Istanbul should be at the same time a paid agent of Rome. France, on the other hand, followed a self-consciously Christian policy. In the 1660s Louis XIV entertained Leibniz's plan for the conquest of Egypt. ${ }^{47}$

As mentioned earlier, the French consuls in the Arab world were in the habit of issuing safe-conduct passes to Arab Christians. These documents were intended to protect them against (western) Christian pirates. Given the religious ambitions of the French crown in the Levant, it is not surprising that the consuls' activity has been interpreted as part of France's mission to bind the Christians of the Eastern Mediterranean more closely to her. ${ }^{48}$ This argument is unconvincing because consuls were happy to provide Muslim merchants and shipowners with passes

\footnotetext{
${ }^{46}$ For a detailed account of French policy and Catholic politics in the Ottoman Empire in the 1620s, see Slot, Archipelagus turbatus, esp. ch. 8.

${ }^{47}$ Paris, Histoire du commerce de Marseille, v, 84.

${ }^{48}$ This is the argument put forward by Robert Haddad, Syrian Christians in Muslim Society: An Interpretation (Princeton, 1970).
} 
as well. ${ }^{49}$ They were little inclined to establish that special relationship with eastern Christians that Césy was pursuing from Istanbul. We can make sense of this seemingly contradictory behaviour only if it is understood that the consuls were at best haphazard executors of French policy.

In the medieval period consuls represented a society of merchants, not the state. Early in the sixteenth century the position of consul was turned into a royal office, as the crown made a concerted effort to raise more money and gain control over a wide array of local and regional institutions. ${ }^{50}$ By the end of the sixteenth century, however, control had been lost again as consulates were transferred to private persons and farmed out many times over. In the sixteenth century it was still the custom for the consul to reside at his post, but this had become exceptional by the seventeenth. Not all consuls even bothered to get a formal appointment, with the result that persons who were socially obscure often represented the French nation. During his visit to Aleppo in 1615, the Grand Vizier refused to allow the European consuls to be seated in his presence, because of rumours that the French consul had previously been a clerk on board ship. ${ }^{51}$

In addition, the fact that the consul's remuneration was rarely sufficient, and always uncertain, means that there is little basis for viewing the consuls as effective executors of French policy. Instead, they were individuals trying to make a living from the office that they had purchased, and the sale of passes was part of that attempt. In short, the government was unable sufficiently to control the consular apparatus, and this worked to diminish the importance of the religious goals that were so central to French missionaries and the French crown. ${ }^{52}$

The Chamber of Commerce of Marseilles, for its part, was frustrated by its lack of control over individuals heading for the Levant. The Levant, and particularly the islands of the Aegean

${ }^{49}$ A consular source from the early eighteenth century indicates that Muslims were regular petitioners. A French corsair, sailing under the Maltese flag, appeared in Levantine waters and 'his presence embarrassed the consuls because Turkish caravaneurs came to ask them for passes and certificates': Cavaliero, 'Decline of the Maltese Corso', 228.

50 'Francis I, 1515-1547, also institutionalized the previously irregular practice of selling offices; the king himself now organized the sale of almost all judicial and financial offices, collecting a fee during private transfers': James B. Collins, The State in Early Modern France (Cambridge, 1995), 17.

${ }^{51}$ Steensgaard, 'Consuls and Nations in the Levant', 28.

${ }^{52}$ Collins, State in Early Modern France, 46. 
with their Catholic populations, provided a convenient refuge for French subjects who had gone bankrupt or engaged in some sort of fraud back home. Once there they often caused friction with the established merchants, both French and local. ${ }^{53}$ Often they turned to piracy. Yet the Chamber could expect little action from the French government as long as ambassadors like Césy were determined to gain the goodwill of the Catholics in the Aegean. As late as the $1670 \mathrm{~s}$ - after the reforms of Colbert which were intended to put French commerce on a firmer footing - the French Ambassador Nointel celebrated Christmas mass on the island of Antiparos with the pirates of the Aegean. ${ }^{54}$ Effective protest was difficult for the Chamber precisely because the seventeenth century was a time of transition. The Chamber no longer controlled the appointment of consuls - the crown had taken over that function - yet communication with the king was not yet routine and was time-consuming and costly. Unlike the English merchants of the Levant Company, the Chamber, and French merchants more generally, had no influence on the appointment of ambassadors. ${ }^{55}$

The French nation itself - that is, the individual merchants trading and living in the ports of the Ottoman Empire - was not a unified body. It was not that the French were particularly fractious: Steensgaard has pointed out that the other western nations in the Levant had their share of differences as well. Rather, the French consul's authority was particularly weak and his decisions, or the decisions of the nation, could be challenged by anyone through recourse to various home authorities back in France. For example, the French nation in Aleppo, summoned by the consul, attempted to impose a boycott on Jewish merchants in the city. All except one voted for it. This individual, however, did not consider himself bound by the decision of the nation. ${ }^{56}$ Perhaps the most spectacular collision amongst the various French interests came in 1623 when Césy had the Ottoman authorities

${ }^{53}$ Xavier Labat Saint-Vincent, 'La Chambre de Commerce de Marseille, trait d'union entre le corps d'Ancien Régime et l'institution consulaire moderne', in Carmel Vassallo (ed.), Consolati di Mare and Chambers of Commerce (Valletta, 1998), 91; Stephanos Yerasimos, 'Introduction', in Joseph Pitton de Tournefort, Voyage d'un botaniste, 2 vols. (Paris, 1982), i, 34.

${ }^{54}$ Slot, Archipelagus turbatus, 206.

${ }^{55}$ See Steensgaard, 'Consuls and Nations in the Levant', for the differences between French and English representation in that region.

${ }^{56}$ Ibid., 42. 
arrest the entire nation in Aleppo, including the consul, because they refused to pay his debts. ${ }^{57}$ Finally, the line separating Frenchmen from local merchants was blurred by the fact that French merchants would lend their names to merchandise carried by Muslim and Jewish merchants (presumably for a fee), in order that the latter could benefit from the protection afforded to Frenchmen. ${ }^{58}$

Commercial competition in the seventeenth century, then, cannot be adequately grasped by thinking in terms of a national or religious division of labour. The search for protection and the weakness of the Mediterranean states are important in understanding why this was so. But there is another reason, derived from the historical specificity of the Mediterranean as the place where Christianity and Islam met (and meet). This weighty legacy coexisted with the new reality of powerful 'northern' states interested in controlling and advancing the fortunes of their own nationals. The result was an ambivalence over which type of community - national or religious - mattered most in the Mediterranean world. Was this a world of religious solidarity, where Christians formed a universal community facing an equally vast and united Muslim world? Or did the reality of state sovereignty modify this picture in important ways?

It is the Mediterranean corso that demonstrates this ambivalence most dramatically. In order to understand why, a few words about this peculiar institution are in order. The corso was not the work of riff-raff; or, at any rate, it was not supposed to be. On both sides of the religious divide, corsairs saw themselves - and, to a certain extent, were seen by others - as participants in an exalted battle against an age-old enemy of the faith. As men of honour and faith, therefore, they were obliged to follow certain rules of engagement. The most fundamental rule concerned the identity of the enemy. For the Christians, all Muslims and all Jews were fair targets. For the Muslim corsairs, the same applied to the Christians. The legitimacy of the corso is demonstrated by the existence of legal forums where victims could come and complain that they had been wrongfully attacked. By this they meant not that the corso itself was wrong, but rather that the rules of the corso had been broken in that particular instance. Clearly, then, the ability to establish the identity of a merchant,

${ }^{57}$ Ibid., 39.

58 Thomas Philipp, The Syrians in Egypt, 1725-1975 (Stuttgart, 1985), 23. 
a ship, its cargo or its crew, was vital. And just as clearly, the real world of commerce and war was a good deal messier than the neat divisions of corsairing rhetoric. The absence of an enforcing state added to the general confusion, as it allowed for a considerable amount of opportunism in deciding on the identity of people and things. ${ }^{59}$

Once again the Greek Orthodox are central to the narrative, this time in their relationship with the Knights of St John. The Greeks highlighted the tension between the ideal of religious solidarity and the reality of state sovereignty precisely because they occupied an oddly intermediary position (and, of course, because they were an important commercial presence): they were both Christians and Ottoman subjects. The Knights of St John, as a Papal order, had their own statutes and according to these the Greek Orthodox, being Christian, were not legitimate targets of (Catholic) Christian attack. ${ }^{60}$ And yet Maltese attacks on Greek shipping were commonplace. Greek Orthodox merchants, captains and shipowners who felt the Knights of Malta had wrongfully attacked them could, and did, go to Malta to protest about their treatment. Often, at least in the first half of the seventeenth century, they obtained redress. It is precisely for this reason that we have, in the historical record, a discussion of the identity of Greek shipping in the Mediterranean. ${ }^{61}$

Greeks in court, of course, emphasized their Christian identity. Maltese corsair captains, who stood accused in court of wrongful attack, skipped lightly over the issue of religion. Rather, they emphasized that the Greeks were subjects of the Sultan. The Maltese corsairs (who, of course, wanted to hold on to their prizes) made it clear that, in their view, the Greeks counted as Turkish. As one corsair put it in 1616, when accused in a lawsuit of wrongfully attacking a Greek, and therefore a Christian, ship: 'The Greeks are always coming here to Malta to cry and pretend to be miserable, having been sent by the Turks to recover their

\footnotetext{
${ }^{59} \mathrm{I}$ will not delve into the motivations of the corsairs in this article; however, it may be that historians have been unduly cynical in dismissing religious motivations out of hand.

${ }^{60}$ The Greek Orthodox were legitimate targets of the Tuscan Order of St Stephen until 1733: H. J. A. Sire, The Knights of Malta (New Haven, 1994), 90-1.

${ }^{61}$ Both Cavaliero and Earle discuss the recourse of the Greek Orthodox to the prize court in Malta: Cavaliero, 'Decline of the Maltese Corso', esp. 233-8; Earle, Corsairs of Malta and Barbary, esp. ch. 5. The prize court in Malta was known as the 'Tribunal Armamentorum'. Its records are stored in Mdina, Malta, where they form part of the National Archives (as opposed to the better known National Library).
} 
goods'. ${ }^{62}$ During times of actual war, such as the last OttomanVenetian war (1714-18), the Knights argued to the Pope that all Greek vessels serving the Turkish fleet in any way - a very broad definition indeed - should be regarded as good prizes. ${ }^{63}$

The Greeks seemed to be sensitive to this charge of working hand-in-glove with the Turks. When the Greek sea-captain Capi Pietro of Lindos came to court to challenge the seizure of his boat, he actually went to the trouble of having Kyrillos, Patriarch of Alexandria, write a statement that he, Capi Pietro, was the sole owner of the boat. ${ }^{64}$ Capi Pietro must have known that the Knights of St John often accused the Greeks of hiding the fact that their boats were partly or completely Muslim-owned. And, in fact, such arrangements were not uncommon in the eastern Mediterranean; so the Knights of St John - given their frame of reference - were right to be suspicious.

Disputes from the Ottoman court in Crete in the 1670s, shortly after the Sultan's conquest of the island from the Venetians, reveal several different possible arrangements. In one case a local Christian sailor co-owned a boat with a Muslim sea-captain from Istanbul. In another a ship regularly engaged in shipping wood from Rhodes to Crete was owned by two Muslims and captained by a Greek. ${ }^{65}$ Greek sailors from the Greek community in Venice in the sixteenth century served on Ottoman Muslim ships as well as Venetian ones. ${ }^{66}$ In the middle of the eighteenth century the merchant marine of Candia (Herakleion), Crete's capital city, was Muslim-owned, but the captains were Greek. In describing this fleet the French consul in Chania wrote: 'The Turks here order their boats from Sfakia. They have quite a number of them and they give them over to Greek captains [to sail]' ${ }^{67}$ Christian and Muslim merchants in Crete were also bound to each other through ties of guarantorship. In 1695, during yet another OttomanVenetian war, two Christian merchants who wanted to depart from Candia with their (unspecified) merchandise had to produce guarantors who would swear that they would not go to Venetian-

\footnotetext{
${ }^{62}$ Earle, Corsairs of Malta and Barbary, 145-6, quoting a Maltese galley captain who appeared in court.

${ }^{63}$ Cavaliero, 'Decline of the Maltese Corso', 234.

${ }^{64}$ Malta, National Archives, Mdina, Tribunal Armamentorum, filza 1, no. 11.

${ }^{65}$ Turkish Archives of Herakleion, vols. 2:138 and 3:92.

${ }^{66}$ Panayiotopoulos, 'Ellenes nautikoi kai ploioktetes', 302.

${ }^{67}$ Quoted in V. Kremmydas, 'Katagrafe ton emborkion plion tou Irakleiou to 1751' [A List of the Commercial Boats of Herakleion in 1751], Mnemon, vii (1978), 16.
} 
occupied Chios. They were able to produce six merchants - two of them Muslim, the other four Christian - who swore that, in the event that the two should enter enemy territory, the guarantors would undertake to apprehend them and turn them over to the Ottoman authorities. ${ }^{68} \mathrm{~A}$ few years later a Christian seacaptain, Georgi reis, enlisted a Muslim sea-captain, Benefșeli Çolak Hassan reis, as his guarantor, so that he would be permitted to export wheat from Crete to North Africa. ${ }^{69}$ Even in Venetian Crete the institution of guarantorship crossed religious lines. ${ }^{70}$

The Greeks also presented special difficulties in one of the perennial headaches that dogged the Knights of St John. It was not uncommon for captured Muslim slaves, once on the island of Malta, to approach the resident Papal Inquisitor and plead that they had originally been Christian. Since, they claimed, they had been forced to abandon Christianity and embrace Islam, their enslavement was unlawful. Former Christians from all over Europe and the Near East - from Holland to Georgia approached the Maltese Inquisitor. The number of Greeks making such claims must have been substantial because in 1641, in response to a request from the Inquisitor, the Papacy sent an Istruzione to the island, designed to help ascertain who was Christian and who was not. These instructions indicate that, at least for westerners, the line between Greek and Turk could be quite indistinct. The letter described how, after corsairing raids in the Archipelago, people would present themselves to the Maltese Inquisitor and declare their Christianity without any authentic documentary proof; this was particularly suspicious because 'in these populations, Christians and Muslims lived side by side'. ${ }^{71}$ A case of pirate attack early in the seventeenth century

${ }^{68}$ Turkish Archives of Herakleion, vol. 8:36.

${ }^{69}$ Ibid., vol. 9:107.

${ }^{70}$ Under the Venetians all ships leaving the port of Candia had to have a guarantor who would vouch that the ship was not carrying slaves or olive oil above the amount permitted for export. In 1611 notarial sources record that Nicolo Cacni q. Luca stood as guarantor for one 'Ghidun turco de faches': Angelike Panopoulou, 'Opseis tes nautiliakes kineses tou Chandaka to 17 aiona' [Aspects of Shipping in SeventeenthCentury Candia], Kretike estia, v (1980), 186.

${ }^{71}$ Archives of the Inquisition of Malta, Corrispondenza, xxvii, fos. 86-7. Part of the text reads: 'Persone, che arrivate in Malta, si dichiarono di Religione Cristiana, senza però darne alcun'autentico documento', but also states that 'in tutti quelli popolazioni promiscuamente vivono Cristiani e Musulmani' (the exact spelling of the word 'Musulmani' is not clear because of the poor quality of the document). It is also cited in Mary Portelli, 'Freed in the Name of Christianity' (Univ. of Malta BA thesis, 1988), 21. 
provides another example of how difficult it was to distinguish Turk from Greek. Alonzo de Contreras stopped a ship manned by Greeks, near the island of Serifos. He was not able to identify the Turks on board (a notable from Athens and his two servants) until torture induced the Greek crew to reveal their passengers' identity. ${ }^{72}$

It is ironic that, at least in the case of the Greeks, the Knights of St John favoured Ottoman state sovereignty over a universal Christian community, despite their self-proclaimed identity as the leaders of the Christian crusade in the Mediterranean. Turning briefly to other maritime powers in the seventeenth century, it should be noted that the North Africans also operated under a territorial, rather than a religious, definition of belonging, although in their case such a definition was used to promote rather than hinder Muslim-Christian trade. The deys of Tunis, Tripoli and Algiers were scrupulous about respecting the merchants, ships and cargoes of those European states with which they had concluded peace treaties. It is true that they were then careful to maintain a state of war with at least one European power, in order to ensure a target for the corso. But this does not change the fact that the definition of the enemy was territorial, not religious. The treaties of 1619 and 1628 between Algiers and France were careful to specify who was, and who was not, a French subject. Italians and Spaniards who were domiciled and resident in France and who were considered to be subjects of the king were to be treated as French subjects. Frenchmen who were found on enemy boats (enemies, that is, of the Algerians), and who were married and lived in the country of the enemy, were to be enslaved as enemies. However, Frenchmen who were found on enemy boats but were nevertheless subjects of the king of France could not be enslaved. ${ }^{73}$ This is worth pointing out, given

${ }^{72}$ A. Krantonelle, Istoria tes peirateias [History of Piracy] (Athens, 1991), 108.

73 'Les Italiens et Espagnols domiciliés et résidans en France qui sont tenus et réputés comme sujets du Roi, seront traités et tenus à l'égal des originaires François'; 'Tous les François qui se trouveront dans les navires de guerre des ennemis d'Alger, et qui seront mariés et habitants aux pays des dits ennemis, estant pris dans tels navires, ils seront esclaves comme ennemis'; and 'Tous ceux qui seront natifs des pays ennemis d'Alger, mais qui seront mariés et habitués en France, ne pourront être faits esclaves, comme aussi se rencontrant quelque François passager sur les navires des dits ennemis, ne pourront estre esclaves pour ce qu'ils soient sujects dudit Empeur de France'. The treaty of 1619 was drawn up at Marseilles in the presence of two deputies sent by the bey of Algiers. The second treaty was signed at Algiers. For the relevant texts, see E. Rouard de Card, Traités de la France avec les pays de l'Afrique du nord: Algérie, Tunisie, Tripolitaine, Maroc (Paris, 1906), 14, 17-18. 
the oft-repeated argument that Muslims were reluctant to accept state boundaries, which, until the modern period, they saw as a brake on the imperative of jihad.

As far as the two imperial powers, the Spaniards and the Ottomans, were concerned, there were groups in both societies who insisted on the permanence of the war between Christianity and Islam. Some Ottoman officials opposed the granting of capitulations to the various European powers, because to do so suggested that 'peace was now a more or less permanent state of affairs' ${ }^{74}$ This attitude finds a mirror reflection in the response of the Spanish Inquisition to a French protest lodged in 1712. The Spaniards in Carthage had seized the captain of a French boat, claiming he was of Jewish origin. The officers of the Inquisition brushed off French protests with the following: 'the ministers of the Inquisition do not answer to the King. Their jurisdiction and their power cannot be limited or impeded by any treaty'. ${ }^{75}$ In short, the commercial world of the seventeenthcentury Mediterranean was characterized by widespread inconsistency and disagreement over the proper balance between the pursuit of commerce and the defence of religion.

\section{III}

\section{A MORE TOLERANT SEA?}

From the last quarter of the seventeenth century the activities and range of Mediterranean corsairs steadily decreased. The Maltese, for reasons which will be discussed below, carried out fewer and fewer cruises into the eastern Mediterranean, concentrating their activities instead on the nearby North African coast. After 1729 it was a very rare year that saw more than three ships licensed by the Grand Master of Malta to pursue the corso in the eastern Mediterranean - whereas twenty to thirty a year had

\footnotetext{
${ }^{74}$ See Faroqhi's interesting discussion of the Ottoman capitulations where she notes that '[c]ertain items in the capitulations ran counter to the deeply held convictions of provincial and local officials. Muslim religious law (the Sharia) assumed that Holy War (gaza) against infidels was permanent, only to be interrupted, at the very most, by brief truces. The granting of capitulations, however, was based upon the assumption that peace was a more or less permanent state of affairs': Faroqhi, 'Trade: Regional, Interregional and International', 481.

${ }^{75}$ Marcel Emerit, 'L'Essai d'une marine marchande barbaresque au XVIII ${ }^{\mathrm{e}}$ siècle', Cahiers de Tunisie, xi (1955), 365.
} 
been common in earlier times. ${ }^{76}$ As for the North Africans, the corso became more and more difficult to sustain as French, English and Dutch firepower improved. The French, for example, bombarded Algiers no less than three times in the 1680s, as part of an ultimately successful campaign to force the Algerians to sign and respect peace and commercial treaties. ${ }^{77}$ The number of Maltese and North African corsairing ships in operation fell dramatically. ${ }^{78}$

If the steady decline of corsairing is viewed in isolation, it might indeed be concluded that its demise signalled the beginning of a more tolerant age. The wider context, however, reveals a rather different process at work. By the end of the seventeenth century the French and the English were strong enough to reshape the contours of Mediterranean commerce so that trade would now serve the state, rather than the disparate goals of individuals of uncertain identity and allegiance. The state, in other words, did not just defend national trade; it was instrumental in its creation. Part of this effort involved reining in the corsairs, both Christian and Muslim, but that did not mean that religion was no longer important in commercial life.

First, once again, the case of France should be examined. Towards the end of the seventeenth century the French government took a number of steps that were designed both to protect French trade and to establish authority over individual Frenchmen and representatives of France. Throughout the century both Barbary and the Maltese corsairs had insisted on the right of visita, the practice of boarding ships to check whether passengers or cargo belonging to the wrong religion (according to the rules of the corso) were on board. This was a practice detested by all merchant captains, including the merchants of Marseilles who, in their determined pursuit of the caravane trade in the Ottoman Empire, naturally carried both. In the year 1673, after sustained pressure from Louis XIV and Colbert, the Maltese agreed to stop employing the visita against French ships (and by

${ }^{76}$ Cavaliero, 'Decline of the Maltese Corso', 235.

${ }^{77}$ Daniel Panzac, Les Corsaires barbaresques: la fin d'une épopée, 1800-1820 (Paris, 1999), 12.

${ }^{78}$ By the mid-1740s both sides had fewer than ten corsair ships at sea. In the seventeenth century the Maltese fleet had fluctuated between twenty and thirty ships while Algiers at her height had as many as seventy or eighty. North African ships were typically much smaller than their Maltese counterparts. Earle, Corsairs of Malta and Barbary, 121-2. 
the end of the century a similar restriction was imposed on the North Africans). ${ }^{79}$ In 1679 Louis XIV issued an order forbidding French subjects from serving on Maltese corsairing ships on cruises in the Levant. ${ }^{80}$ More generally, he exerted heavy pressure on the Knights to withdraw their ships from that area; various threats were issued, such as the seizure of all the Order's possessions in France. ${ }^{81}$ Although it took a little longer (until the 1730s), French consuls in the Levant were brought into line and stopped issuing safe-conduct passes to Arab-Christian shipping. The practice was stopped precisely because Arab-Christian shipping represented a threat to French dominance: 'These saiques have seriously diminished the profit which French ships used to enjoy in carrying out the caravane trade'. ${ }^{82}$

Part of the work of building a national trade policy was a clearer separation between Frenchmen and others in the Mediterranean. In 1685 the Marseilles Chamber of Commerce was finally granted its wish and was given jurisdiction over all the French who hoped to establish themselves in the Levant. From now on individuals had to be examined and approved by the Chamber. Louis XIV then moved swiftly to try both to clear unauthorized French subjects out of the Aegean islands and to break the ties of marriage and property that had developed between Frenchmen and locals. Whereas previously the Catholics - French and others - of the Aegean had been admired and courted, the king's emissary, Pitton de Tournefort, had nothing but scorn for the French colony on the island of Sikinos, which he visited in 1700 :

There is no harsher punishment for an old sinner than to marry in Greece. Ordinarily the women that they marry are without virtue or property; and yet one sees many doing this, despite the vigorous prohibition of the King who, for the honour of the nation, has very wisely ordained that none of his subjects be allowed to marry in the Levant without permission of the King's ambassador or one of his agents. ${ }^{83}$

But Sikinos was the only island which still boasted a substantial French population; by 1700 the number of Frenchmen living in

${ }^{79}$ Ibid., 112, 41.

${ }^{80}$ Sire, Knights of Malta, 91.

${ }^{81}$ Cavaliero, 'Decline of the Maltese Corso', 231.

${ }^{82}$ Philipp, Syrians in Egypt, 23. It is not clear when France stopped issuing safeconduct passes to Muslim shipping. Presumably it was around the same time.

${ }^{83}$ Slot, Archipelagus turbatus, 238. 
the Aegean had dropped dramatically. ${ }^{84}$ Further west, in 1692, French officials inserted a clause intended to discourage French conversion to Islam into their latest peace treaty with Algiers. ${ }^{85}$

All these measures, however, did not usher in an age of normalized trading relations where merchants and ships could move freely about the Mediterranean, nor was this intended. Here attention can be drawn once again to the merchants and the Chamber of Commerce of Marseilles. In the writings on seventeenth-century French commerce, Marseilles is presented as the home of pragmatic and cosmopolitan businessmen who wanted a Mediterranean free of religious confrontation and corsairing: 'Whether it was a question of Constantinople or the Barbaresques, they obstinately defended and worked for the triumph of a politics of entente rather than conflict, a politics which their long experience of the Turkish world had shown them was the only profitable road to follow' ${ }^{86}$ This statement is only partly true. Certainly French merchants were determined that the Knights of Malta and other Christian corsairs should not stand in the way of French trade with the ports of the eastern Mediterranean. But closer to home they were equally determined to make the port of Marseilles off-limits to North African merchants, and they were prepared to make use of both the Knights of St John and anti-Muslim sentiment in order to do so.

As profits from the corso began to decline towards the end of the seventeenth century, the North Africans made some attempts to develop a commercial shipping capacity, but they were ultimately unsuccessful. ${ }^{87}$ Some of the reasons for this, such as an inadequate supply of wood, were quite unrelated to cultural or religious questions. But it is also clear that, as Muslims, the North Africans had to face continuing religious hostility. The corso had been forced to withdraw from the eastern Mediterranean, but it still raged along the North African coasts. ${ }^{88}$ As late as 1788 , just

${ }^{84}$ Ibid., 237-8.

${ }^{85}$ The clause stated that any Frenchman who wanted to 'turn Turk' had to wait three days at the French consulate to make sure that the conversion was voluntary: Emerit, 'L'Essai d'une marine marchande barbaresque', 364.

${ }^{86}$ Paris, Histoire du commerce de Marseille, v, 79.

${ }^{87}$ For accounts of these attempts, see L.Valensi, On the Eve of Colonialism: North Africa before the French Conquest (New York, 1977); Emerit, 'L'Essai d'une marine marchande barbaresque'; Sadok, La Régence de Tunis.

88 'The period following 1723 has been described by historians of the Order of St John as one of naval decline. For all its prevalence, this view is founded on a primal ignorance of the area most relevant to the question - the development of the North African states': Sire, Knights of Malta, 94. 
ten years before Napoleon abolished the Knights of Malta, seventy-eight North African prizes were seized and taken to Malta; ${ }^{89}$ and in 1795 the Papal navy captured eighty-eight Muslims on the high seas. ${ }^{90}$ Not only did the French fail to move to curb this corsairing activity, but they were quick also to recognize the advantage it gave to French shipping. Writing in 1790, the French chargé d'affaires in Malta underlined the significance of Christian corsairing: 'The continued prosperity of Marseille's trade, which provides the Order with substantial tokens of concern for it, requires that we attempt to keep the Turks from carrying merchandise on their own vessels, thus keeping them dependent on us'. ${ }^{91}$

If Maghribi sea-captains could make it through the gauntlet of the corso, they faced the formidable barrier of European protectionism. Those who were persistent enough actually to sail into a port in southern Europe were confronted with harassment designed to discourage them from making the attempt again. North African Muslim merchants found that, when they arrived in Marseilles, there was no storage space for their goods. They were accused of being pirates and forbidden to sail into the harbour; translators could not be found for them; and so on. ${ }^{92} \mathrm{~A}$ memorandum published in Naples in 1786 argued that Europe should open her ports to the North Africans, thus making it clear that these ports were, in fact, considered off-limits, despite the occasional ship that made it through.

This little-known history could explain the rather different view of the seventeenth century held by H.-D. de Grammont, the nineteenth-century historian of Algeria. In 1882 he wrote: 'Our sailors, and those along the Mediterranean coast, nourished an undying hatred for Barbary. They never missed an opportunity to attack them, and it did not matter to them if His Majesty's government was at peace with the Regency or not'. ${ }^{93}$ De Grammont presents the people of Mediterranean France as a rogue population and this may have something to do with

${ }^{89}$ Valensi, On the Eve of Colonialism, 48.

${ }^{90}$ Salvatore Bono, 'Esclaves musulmans en Italie', in La Méditerranée au XVIII siècle: actes du colloque international tenu à Aix-en-Provence, les 4, 5, 6 septembre 1985 (Aix-en-Provence, 1987), 191.

${ }^{91}$ Valensi, On the Eve of Colonialism, 48.

${ }^{92}$ Emerit, 'L'Essai d'une marine marchande barbaresque', 368-9.

${ }^{93}$ H.-D. de Grammont, 'Un Académicien captif à Alger, 1674-1675', Revue africaine, xxvi (1882), 312. 
nineteenth-century colonial politics. Nevertheless, there is support for his views. For example, in 1674 eight Algerian Turks fled the Spanish galleys and sought refuge in a French port, given that France and Algeria were then at peace. But the unfortunate runaways were seized and sent to the galleys of Marseilles. Following protests from the dey of Algiers, Colbert ordered their release but his instructions were not followed. ${ }^{94}$ In Paris the view may have been that the corso was over, but that sentiment was not necessarily endorsed in Marseilles. The inability of the Sultan in Istanbul to control his North African subjects has been stressed over and over in the relevant literature. Yet the relationship of Paris to the coasts of Languedoc and Provence has received very little attention. ${ }^{95}$ Whatever the reality, the 'tolerance' of the eighteenth century is much more difficult to find in the western Mediterranean than it is in the east.

The continuing prominence of religion emerges in sharp relief when comparing the difficulty of the North African position with the very different experience of the Greeks. Faced with a crisis at the end of the seventeenth century, the Greeks were able to use their Christian identity to good advantage. Greek caravaneurs, at least in the eastern Mediterranean, managed to hold their own against the French throughout much of the seventeenth century. But France's ability to impose her will on the Maltese in the 1670 s - when their right to use the visita on French ships was taken away - boded ill for the Greeks. Prior to this, while the Greeks had certainly suffered their share of piratical assaults, at least they had not been singled out for attack. But now that French shipping, which was very considerable, was off-limits to the Maltese, they redoubled their assault on the Greeks, the only competitors to the French in the caravane trade of the Empire. To make matters worse, Greek shippers and merchants found that the courts in Malta were no longer sympathetic to charges of wrongful (that is, religiously illegitimate) depredation. What happened next is quite telling. The Papacy came to the defence

${ }^{94}$ Earle, Corsairs of Malta and Barbary, 39-40.

${ }^{95}$ This is all the more remarkable considering that in 1660 Marseilles, the capital of French trade with the Mediterranean, was occupied by the French army and a section of its wall demolished. 'Marseilles was treated virtually as a conquered city': Robin Briggs, Early Modern France, 1560-1715 (Oxford, 1977), 143. 
of the Greeks. This defence took two forms. The Pope - operating through the Papal Inquisitor in Malta - allowed, indeed encouraged, the Greeks to bring their complaints to Rome, where they would be given a fair hearing. The first instance of this seems to have been in 1705, and after that the volume of cases going to Rome quickly grew. ${ }^{96}$ The Greeks were so successful in their claims in Rome that the Knights sent an emissary, one Chevalier Morosini, to the Papacy in 1716 to complain (choosing the strategic moment of the last Ottoman-Venetian war), but to no avail. At the same time, the Papacy, again working through the Maltese Inquisitor, put pressure on the Knights to end the corso in the Levant. In 1702 the Inquisitor demanded a general recall of all Maltese ships in those waters. ${ }^{97}$

This was not the first time that the Greeks turned to the Papacy for support, both in Malta and in the wider world of the eastern Mediterranean. In 1614 the Pope had asked the Knights of St John to stop attacking the monks at the Monastery of St John on the island of Patmos. ${ }^{98}$ On Malta itself the Inquisitor was in the habit of visiting the Knights' ships from time to time to make sure that no 'Coptics, Greeks, Armenians, Syrians and others' were being held against their will. ${ }^{99}$ The fact that the Greeks could still make such an appeal at the beginning of the eighteenth century testifies to the enduring power of religion in the Mediterranean. ${ }^{100}$

The Knights of Malta, then, were being forced to fight a battle against both the French and the Papacy in order to keep the corso alive in the eastern Mediterranean. What is interesting is that, in their protests, the Knights used different strategies, depending upon whom they were addressing. With the French the emphasis was on national competition, while the appeal to the Papacy was couched in terms of the old religious rhetoric.

In 1720 the Grand Master wrote to the Order's ambassador in Paris, instructing him to point out that '[i]f the Maltese corso stopped in the Levant, the French flag would not be respected

${ }^{96}$ A Greek complaint against Giuseppe Preziosi, Chevalier of St Mark, was taken to Rome by order of the Pope: Cavaliero, 'Decline of the Maltese Corso', 233.

${ }^{97} \mathrm{Ibid}$.

${ }^{98}$ Krantonelle, Istoria tes peirateias, 95.

${ }^{99}$ A. Bonnici, Medieval and Roman Inquisition in Malta (Rabat, 1988), 47.

${ }^{100}$ The Pope was certainly more motivated by a desire to meddle in the Knights' affairs than he was by enthusiasm for Greek Orthodoxy. This does not change the fact that the Greeks could elicit a response from him based on their Christian identity. 
as it is, and Greeks would take up the commerce of those waters and wrest it from the French'. ${ }^{101}$ Writing to Rome in the same year, Zondadari stressed Muslim-Christian antagonism even though his real target was the Greeks: 'If there were no Corso, the Turks would be free to practice seamanship and to wrest the control of the inner seas from the Christians'. ${ }^{102}$ Two years later the new Grand Master, de Vilhena, wrote again to Rome:

not being in any way able to support so many families reduced to the most deplorable poverty by the far too indulgent favour shown to the Greeks, we shall be forced with great displeasure to introduce open commerce with the common enemy and thus break the strictest rule of our statute. ${ }^{103}$

The Maltese were very correct in suggesting to the French that, if the corso were stopped in the eastern Mediterranean, the Greeks would be the beneficiaries. By the second decade of the eighteenth century Muslim shippers were already starting to come back to the Greek caravane which they had temporarily abandoned in favour of the French. ${ }^{104}$ Thus the French, by reining in the Maltese corso, inadvertently assisted in the revival of Greek shipping, whilst French complaints about competition from the Greeks, first in the caravane trade and later in the international arena, became a staple of the eighteenth century. ${ }^{105}$

The alliance between the Papacy and the Greeks reveals that a Christian identity was still advantageous, even in the supposedly more secular age of the eighteenth century. By the late eighteenth century Greek merchants were well established in Livorno, Marseilles and other cities of southern Europe. These were cities whose ports were not open to North Africans. To return briefly to the question of French policy, it is true that the primary goal was to reserve Levantine commerce for the French rather than to discriminate against Muslims per se. Nevertheless, the fact remains that it proved easier to exclude Ottoman Muslims than Ottoman Christians from Europe.

${ }^{101}$ Cavaliero, 'Decline of the Maltese Corso', 231.

102 Ibid., 235.

${ }^{103} \mathrm{Ibid}$.

${ }^{104}$ Earle, Corsairs of Malta and Barbary, 116; Cavaliero, 'Decline of the Maltese Corso', 235. In 1724 the Grand Master complained to the Pope about the 'growing practice of the Turks' to use Greek merchants for cover: Cavaliero, 'Decline of the Maltese Corso', 236.

${ }^{105}$ As Stoianovich pointed out many years ago: 'France is thus in a sense the instigator of the decline of her own caravane trade. Her policy permits the decline of the Maltese corso and in this way she encourages, indirectly, the Greco-Albanian 


\section{CONCLUSION}

In the rush to proclaim (or deplore) Europe's triumph in the Mediterranean world, it is easy to overlook the distinctiveness of the seventeenth century. Running through many of the conflicts of the time was a question that perfectly reflected the ambiguous position of the Mediterranean: should commerce take heed of the new claims of state sovereignty, or should it continue to be shaped by the tradition of religious warfare? It is striking how resonant that question - in an altered form, of course - continues to be today. Do the countries surrounding the Mediterranean share something in common around which they can, or should, unite? Or is the Mediterranean rather a border zone, a place where two more or less hostile civilizations meet? It was a question that would remain unanswered throughout the seventeenth century. It is this indecision that explains the ambiguity, the hesitation, and the interest of that historical moment.

Princeton University

Molly Greene 